\title{
Behavior Regulation Index
}

National Cancer Institute

\section{Source}

National Cancer Institute. Behavior Regulation Index. NCI Thesaurus. Code C121482.

An index of the Behavior Rating Inventory of Executive Function that captures the individual's ability to shift cognitive set and modulate emotions and behavior via appropriate inhibitory control. It combines the Inhibit, Shift, and Emotional Control scales. 